\title{
ELSA Speak Application as a Supporting Media in Enhancing Students' Pronunciation Skill
}

\author{
Ita Sarmita Samad ${ }^{*}$, Ismail ${ }^{2}$ \\ 1-2English Education Program, Universitas Muhammadiyah Enrekang, Indonesia \\ Email: itaneverendita@gmail.com ${ }^{1 *}$; ismail@ummaspul.ac.id $^{2}$
}

\begin{tabular}{|c|c|}
\hline ARTICLE INFO & ABSTRACT \\
\hline Article History: & This research aimed at verifying the effectiveness of using ELSA \\
\hline $\begin{array}{l}\text { Received June 01, } 2020 \\
\text { Revised July 07, } 2020 \\
\text { Accepted July 13, } 2020\end{array}$ & $\begin{array}{l}\text { Speak Application in enhancing students' pronunciation skills. It } \\
\text { applied a quantitative method. It used a pre-experimental } \\
\text { research design, in particular. The population was STKIP } \\
\text { Muhammadiyah Enrekang's English study programme. The } \\
\text { sample was the first semester students in the academic year } \\
\text { 2018/ 2019. It was chosen through purposive sampling }\end{array}$ \\
\hline Keywords: & \\
\hline $\begin{array}{l}\text { ELSA Speak Application, } \\
\text { Pronunciation Skill, } \\
\text { Teaching Media }\end{array}$ & $\begin{array}{l}\text { by pre-test and post-test. The results were statistically analysed. } \\
\text { The result shows that the pre-test results display a value of } 1.96 \text {, } \\
\text { while the mean after test is } 5.79 \text { with a significance level of } 0.05 \\
\text { at } 29 \text { degrees (29), the t-test } 6.28 \text { was higher than the t-table of } 1 \\
699 \text {. It indicated that the use of ELSA Speak application is } \\
\text { effective in enhancing the pronunciation skill of the first } \\
\text { semester students of STKIP Muhammadiyah Enrekang. }\end{array}$ \\
\hline
\end{tabular}

(C)2020. This is an open-access article under the CC BY-SA license (C) () () (http://creativecommons.org/licenses/by/4.0/)

\section{Introduction}

It comes as no surprise that the globalization process has given a big influence in many sectors of life. There is no doubt that it engenders cultural, political, economic, scientific, educational, technological, and information exchange (Mustakim, M., \& Lateh, N., 2020). In the same time, the needs of translators or interpreters as a mediator are also raised. Therefore, to avoid misunderstanding, the interpreter must have good pronunciation skills that can lead to the success of communication.

Unfortunately, pronunciation skill is still one of the major issues among foreign language learners (Fraser, $\mathrm{H}$., 2006). Even, those who are studying in university still face difficulties. It is not a surprise as they will be influenced by 
their native language. For instance, Indonesia has many different dialects or accents based on their region. Then, most of the Indonesian students' pronunciation will be affected by their dialect and thus their foreign language will be sounded unnaturally.

Indeed, the students of STKIP Muhammadiyah Enrekang encounter the problem above as well. They generally come from Enrekang Regency and have various dialects. Therefore, most of them will be affected by their dialect when they are pronouncing words or sentences. Consequently, there must be an effective solution to solve this matter.

Regarding the world has been entering the industrial revolution 4.0 then the teaching media used in teaching and learning process should refer to 9 trends of 4.0 kinds of learning (Degest, 2019). One of them is that the teaching media is mostly digital-based and can be taken anywhere and anyplace. The process of learning must not only be taken in the class yet the students can access it outside via online educational application (Ismail, I., Elihami, E., \& Mustakim, M., 2019). Thus, they can keep in touch with the learning process easily through the media wherever they are. It can be safely assumed that the students will enjoy that kind of learning since almost all of them are active internet users.

To sum up, the era 4.0 education should support the students to learn independently. The learning is shaped to student-centered. It allows the students to learn by their selves utilizing various sources of media. The teachers' role is as a facilitator to guide the students in their learning (Purnama, Y., et al. 2020). The process of teaching and learning focuses instead on the teacher or the instructor.

ELSA Speak application is one of the media that can support era 4.0 education. ELSA stands for English Language Speech Assistant. It is an application for android that can be freely downloaded from AppStore or Google play. It is designed with various features to improve the learners' pronunciation with the American accent by exercising them with various practices to pronounce a word/ phrase/ sentence correctly. It is completed with a microphone icon that the learner can use it directly to practice to speak like the audio has been listened.

A previous related study examined the perception of students in their pronunciation class of the ELSA Speak application (Samad \& Aminullah, 2018). The study concluded that the students feel that the software is appropriate for teaching and learning. This app also features 7 Best English Pronouncement Apps (2019), which help students talk English clearly, smoothly and confidently.

The researcher aims to investigate the use of ELSA Speak in improving student pronunciation skills based on its context. It aims at answering the research question which investigates whether or not the ELSA Speak app can improve the students' pronunciation skills.

This research is expected to have theoretical and practical significances. Theoretically, it gives valuable input for the teacher related to media used in the teaching and learning process. Besides, it is expected that the result of this research can support the 4.0 educational system. Practically, it is hoped that the students can enjoy learning through the ELSA Speak 
application and thus it can improve their pronunciation skills. Besides, it is expected that students can learn independently. For the researcher, it is expected that this research can be a good way to enhance her professionalism in teaching as a lecturer.

\section{Method}

This research applied experimental research design. Specifically, it used pre-experimental design since the total class of the students who takes the pronunciation course is only one class and thus it was not possible to apply the quasi-experimental design. The population is the English Education students of STKIP Muhammadiyah Enrekang in the academic year 2018/ 2019 and the sample is the first semester students of the program.

In this study, the instruments used were pre-test and post-test. It consisted of 35 items which 30 items of it is to test the students' word pronunciation. Meanwhile, the rest 5 items were used to test the students' sentence pronunciation. In terms of the word pronunciation test, the score given for each item was 1 and for the sentence pronunciation test, the score given for each item was 2 . The table 1 illustrated the scoring system clearly.

\section{Table 1. The Scoring System of the Test}

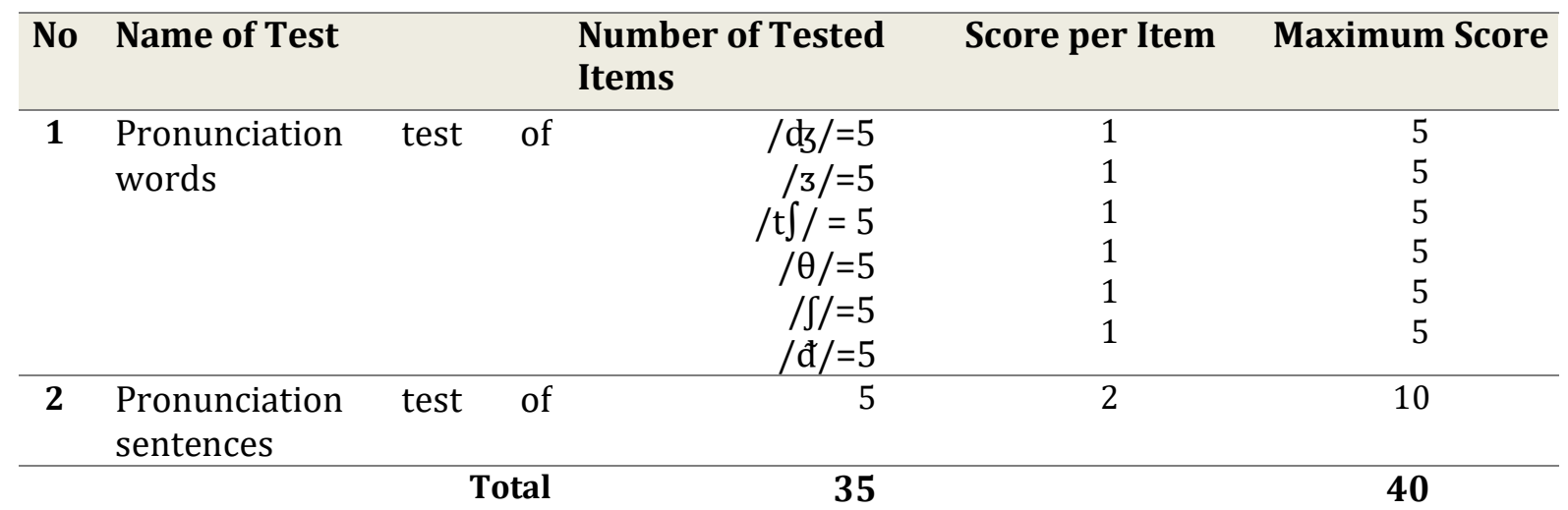

Treatment was conducted after the pre-test. The students learned how to pronounce the six consonant sounds correct by using the ELSA Speak application. They had been asked to download this app through AppStore or play store on their own smartphone or gadget. The treatment was given for 8 meetings. Afterward, the post-test was given. Principally, it was no different from the pre-test previously in terms of its forms, items, difficulties, and scoring system. Besides, the researchers utilized a video recorder during the test to facilitate them in analyzing the students' pronunciation.

The data collected was analyzed through some steps. The first, the researcher measured the students' individual scores by applying the formula suggested by Sutomo (1985:23) as follows: 


$$
\text { Individual Score }=\frac{\text { Obtained Score }}{\text { Maximum Score }} \text { X } 10
$$

The second is the researcher calculated the mean score by applying the formula stated by Arikunto (2006:189) as follows:

$$
\mathrm{M}=\frac{\Sigma x}{N}
$$

Where: $\mathrm{M}=$ Mean Score

$$
\begin{aligned}
& \Sigma x=\text { The number of score } \\
& \mathrm{N}=\text { Number of students }
\end{aligned}
$$

The third is the researcher calculated the students' mean deviation by applying the following formula which is stated by Arikunto (2002:276).

$$
\mathrm{Md}=\frac{\Sigma d}{N}
$$

Where: $\mathrm{Md}=$ Medium score between pre-test and post-test $\Sigma d=$ Score deviation between pre-test and post-test $\mathrm{N}=$ Number of students

The fourth is the researcher determined the sum of deviation squared based on the formula of Arikunto (2006: 308)

$$
\Sigma \mathrm{x}^{2} \mathrm{~d}=\Sigma \mathrm{d}^{2}-\frac{(\Sigma \mathrm{d}) 2}{N}
$$

Where: $\Sigma \mathrm{x}^{2} \mathrm{~d}=$ The sum of deviation squared in each subject

$$
\begin{aligned}
& \Sigma d^{2}=\text { Sum of squared deviation } \\
& N=\text { Number of students }
\end{aligned}
$$

Finally, the researcher computed the t-test score as follows:

$$
\begin{aligned}
& t=\frac{M d}{\sqrt{\frac{\sum \times 2 d}{N(N-1)}}} \\
\text { Where: } t & =\text { Significant score } \\
\text { Md } & =\text { Medium score between pre-test and post-test } \\
\Sigma \mathrm{x}^{2} \mathrm{~d} & =\text { The sum of deviation squared in each subject } \\
\mathrm{N} & =\text { Number of students } \\
1 & =\text { Constant Number }
\end{aligned}
$$

\section{RESULTS AND DISCUSSIONS}

The result of the students' pre-test is shown through the following table.

Table 2. The Students' Pre-Test Score

\begin{tabular}{llcccc}
\hline \multirow{2}{*}{ No. } & Initial Names & \multicolumn{2}{c}{ Types of Test } & \multicolumn{2}{c}{ Total Score } \\
\cline { 3 - 6 } & & $\begin{array}{c}\text { Words } \\
\text { Pronunciation }\end{array}$ & $\begin{array}{c}\text { Sentences } \\
\text { Pronunciation }\end{array}$ & Raw Scores & Individual Scores \\
\hline 1 & AFS & 11 & 3 & 14 & 3.5 \\
2 & EMI & 7 & 3 & 10 & 2.5 \\
3 & MY & 1 & 0 & 1 & 0.25 \\
4 & MHD & 6 & 5 & 11 & 2.75 \\
5 & MMF & 3 & 5 & 16 & 4 \\
6 & NAT & 5 & 2 & 5 & 1.25 \\
7 & NMJ & 2 & 2 & 7 & 1.75 \\
8 & NHK & 6 & 2 & 4 & 1 \\
9 & PRT & 6 & 5 & 9 & 2.25 \\
10 & RHD & 3 & 1 & 11 & 2.75 \\
11 & RTA & 2 & 0 & 4 & 1 \\
12 & RSI & $\mathbf{6 3}$ & $\mathbf{3 1}$ & 2 & 0.5 \\
\hline & Total Score & & & $\mathbf{9 4}$ & $\mathbf{2 3 . 5}$ \\
\hline
\end{tabular}


The highest score for pre-test students was 4 while the lowest score was 0.25 in Table 2 . The researcher has calculated the data on the basis of the previously explained formula to obtain the mean score of the pre-test and the result is 1.96 . It shows that the pronunciation skills of the student are extremely poor.
Once the students had been treated, the researcher then tested the students for advances in the pronunciation skills of the students. Furthermore, it is a way to determine whether or not the pronunciation skills can be improved by means of an application for ELSA Speak. The result of the post-test can be seen in the following table.

Table 3. The Students' Post-Test Score

\begin{tabular}{|c|c|c|c|c|c|}
\hline \multirow[b]{2}{*}{ No. } & \multirow[b]{2}{*}{ Initial Names } & \multicolumn{2}{|c|}{ Types of Test } & \multicolumn{2}{|c|}{ Total Score } \\
\hline & & $\begin{array}{c}\text { Words } \\
\text { Pronunciation }\end{array}$ & $\begin{array}{c}\text { Sentences } \\
\text { Pronunciation }\end{array}$ & Raw Scores & Individual Scores \\
\hline 1 & AFS & 25 & 5 & 30 & 7.25 \\
\hline 2 & EMI & 14 & 5 & 19 & 4.75 \\
\hline 3 & MY & 17 & 5 & 22 & 5.5 \\
\hline 4 & MHD & 11 & 2 & 13 & 3.25 \\
\hline 5 & MMF & 27 & 6 & 33 & 8.25 \\
\hline 6 & NAT & 21 & 5 & 26 & 6.5 \\
\hline 7 & NMJ & 9 & 4 & 13 & 3.25 \\
\hline 8 & NHK & 19 & 5 & 24 & 6 \\
\hline 9 & PRT & 24 & 5 & 29 & 7.25 \\
\hline 10 & RHD & 11 & 2 & 13 & 3.25 \\
\hline 11 & RTA & 23 & 5 & 28 & 7 \\
\hline 12 & RSI & 23 & 6 & 29 & 7.25 \\
\hline & Total Score & 224 & 55 & 279 & 69.5 \\
\hline
\end{tabular}

The highest score in post-test students is 8.25 while the lowest score is 3.25. Table 3 reveals. The researcher then calculated the average post-test score using the previously mentioned formula. The average score is considered to be 5.79 .

Based on the above results, it is known that the pre-test for the students is 1,96 , and the post-test score for the students is 5,79. It means that the average score for the pre-test is less than the average score for the post-test students. In other words, after diagnosis, the performance of the students is increased.

The average pre- and post-test deviation score is 3.83 and the total deviation is 49.92. They are as follows calculated.

$$
\begin{aligned}
\mathrm{Md} & =\frac{\Sigma d}{N} \\
& =\frac{46}{12} \\
& =3.83
\end{aligned}
$$




$$
\begin{aligned}
\Sigma x 2 d & =\Sigma d 2-\frac{(\Sigma d) 2}{N} \\
& =226.25-\frac{(46) 2}{12} \\
& =226.25-\frac{2116}{12} \\
& =226.25-176.33 \\
& =49.92
\end{aligned}
$$

The calculation is continued to count on the t-test score. It aims at finding out whether the research hypothesis is accepted or rejected. The computation can be seen below.

$$
\begin{aligned}
\mathrm{t} & =\frac{M d}{\sqrt{\frac{\sum \mathrm{x} 2 \mathrm{~d}}{N(N-1)}}} \\
& =\frac{3.83}{\sqrt{\frac{49.92}{12(12-1)}}} \\
& =\frac{3.83}{\sqrt{\frac{49.92}{12(11)}}} \\
& =\frac{3.83}{\sqrt{\frac{49.92}{132}}} \\
& =\frac{3.83}{\sqrt{0.38}} \\
& =\frac{3.83}{0.61} \\
& 6.28
\end{aligned}
$$

The results show that $\mathrm{t}$-counted is 6.28 with a value of 0.05 at 29 degrees of liberty (df), based on the analytics of the data. The t-count (6.28) indicates that the t-table was higher (1.699). Thus, it can be concluded that the research hypothesis was accepted. In other words, ELSA Speak Application is effective in enhancing the pronunciation skill of the first semester students of STKIP Muhammadiyah Enrekang.

\section{Conclusion}

Finally, the researcher draws some conclusions which are based on the data analysis described previously. The first, ELSA Speak Application can enhance the students' pronunciation skills. It is proved by seeing the result of the posttest score (5.79) that is higher than the students' pre-test score (1.96). The second, ELSA Speak is an effective medium to be used in supporting the students in improving their pronunciation skills. Thus, this application is highly recommended for supporting the pronunciation class.

\section{References}

1) 7 Best English pronunciation Apps. (2019). Retrieved from https://englishpost.org/bestenglish -pronunciation-apps

2) Arikunto, S. (2002). Prosedur penelitian: Suatu pendekatan praktek. (5 ${ }^{\text {th }}$ ed.). Jakarta: Rineka Cipta.

3) Arikunto, S. (2006). Prosedur penelitian: Suatu pendekatan praktek. $\quad\left(6^{\text {th }}\right.$ ed.). Jakarta: Binarupa Aksara.

4) Degest. (2019). Bantuan hibah penelitian 2019 SEAMOLEC. Retrieved from 
http://www.guruberbagi.net/2019/0 1/bantuan-hibah-penelitianseamolec-2019.html

5) Fraser, H. (2006). Helping teachers help students with pronunciation: A cognitive approach.

6) Ismail, I., Elihami, E., \& Mustakim, M. (2019). Students' Perceptions of the Benefits of Mobile Polling Technology in Teaching and Learning in College: Implications of Students' Participation and academic Performance. Jurnal Pendidikan Progresif, 9(1), 89-104. Retrieved from http://jurnal.fkip.unila.ac.id/inde x.php/jpp/article/view/17871

7) Marnalita, Syafar, A., \& Erniwati. (2013). Using audio Cambridge advanced learner's dictionary (CALD) to improve English pronunciation. e-Journal of English Language Teaching Society (ELTS), 1(1), 1-13.

8) Mustakim, M., \& Lateh, N. (2020). Multicultural Education in Interlanguage English Textbooks for Senior High School Students in Maroangin. MAJESTY JOURNAL, 2(1), 10-19. https://doi.org/10.33487/majest y.v2i1.320
9) Samad, I. S., \& Aminullah. (2018). Applying ELSA speak software in the pronunciation class: students' perception. Edumaspul-Jurnal Pendidikan, 3 (1), 56-63.

10) Sutomo. (1985). Teknik penilaian dan penelitian. Surabaya: Bina Ilmu.

11) Purnama, Y., Ismail,. I., Noviandri,. D., Hendriyani, . Y., Nguyen, . P. T. \& Darmawan,. I.P.A. (2020) Expert System in Detecting Children's Intelligence using Certainty Factor. Journal of Critical Reviews, $7 \quad$ (1), 52-55. doi:10.22159/jcr.07.01.09 